\title{
Assessment of genetic diversity among surian Toona sinensis Roem in progenies test using random amplified polymorphic DNA markers
}

\author{
Jayusman ${ }^{1,2, *}$, Muhammad Na'iem² ${ }^{2}$ Sapto Indrioko², Eko Bhakti Hardiyanto ${ }^{2}$, and ILG Nurcahyaningsih ${ }^{1}$ \\ ${ }^{1}$ Centre for Forest Biotechnology and Tree Improvement Research and Development, Jalan Palagan Tentara Pelajar Km. 15, \\ Purwobinangun, Pakem, Sleman, Yogyakarta 55582, Indonesia \\ ${ }^{2}$ Faculty of Forestry, Universitas Gadjah Mada, Jalan Agro No. 1, Bulaksumur, Yogyakarta 55281, Indonesia \\ *Corresponding author: yusblora2003@yahoo.com
}

\begin{abstract}
Surian Toona sinensis Roem is one of the most widely planted species in Indonesia. This study aimed to estimate the genetic diversity between a number of surian populations in a progeny test using RAPD markers, with the goal of proposing management strategies for a surian breeding program. Ninety-six individual trees from 8 populations of surian were chosen as samples for analysis. Eleven polymorphic primers (OP-B3, OP-B4, OP-B10, OP-H3, OP-Y6, OP-Y7, OP-Y8, OP-Y10, OP-Y11, OP-Y14, and OP-06) producing reproducible bands were analyzed for the 96 trees, with six trees per family sampled. Data were analyzed using GenAIEx 6.3, NTSYS 2.02. The observed percentage of polymorphic loci ranged from $18.2 \%$ to $50 \%$. The mean level of genetic diversity among the surian populations was considered to be moderate (He 0.304). Cluster analysis grouped the genotypes into two main clusters, at similarity levels of 0.68 and 0.46 . The first two axes of the PCoA explained $46.16 \%$ and $25.54 \%$ of the total variation, respectively. The grouping of samples into clusters and subclusters did not correspond with family and their distances, but the grouping was in line with the genetic distances of the samples.
\end{abstract}

KEYWORDS genetic diversity; progeny test; RAPD; Toona sinensis

\section{Introduction}

Surian Toona sinensis Roem (family Meliaceae) is widely distributed and cultivated in Southeast Asia including India, Nepal, Thailand, Malaysia, Australia, the Philippines, and Indonesia (Pennington and Styles 1975; Edmonds and Staniforth 1998). In Indonesia this species can be found in several islands in agricultural lands owned by community forests (Pramono et al. 2008). Surian is a valuable and fast growing timber species whose wood is reddish, hard, and shiny with a beautiful grain. Its timber is excellent in construction, interior decoration, furniture, musical instruments, shipbuilding and other fields. Its bark fiber can be used to make paper. Its bark, flower, leaf and oil from seed extracted have been used in traditional medicine. Compared with other species, it is more conducive to plant all around, and can be used as the main tree species in green and farm land all around in agroforestry (Zhou et al. 2010). These domesticated resources are important and valuable germplasm for surian breeding (Xing et al. 2016).

In most forest tree improvement programs around the world, progeny tests are used to estimate breeding values of selections (Zobel and Talbert 1984). The establishment of a progeny trial is complex. It is a challenge to maintain the correct identity of entries during the entire chain of events associated with the preparation of a progeny test, such as seed collection, cleaning, stratification, nursery propagation, lifting, seedling transport and storage, planting and mapping. Furthermore, information about which seedlings may be paternal half-sibs is usually completely unavailable to breeders who use open-pollinated seeds. To address the problem of seedling identity and to gain access to additional information about paternity, tree breeding programs have been initiated by utilizing DNA-based markers to infer the relationship structure among progenies (Gaspar et al. 2008). Along with providing information on the identities of progeny and their relatives, breeding programs can be optimized by combining genotypic information, avoiding the costs associated with controlled pollinations and capitalizing on the assembly of natural crosses among selected parents into structured progeny arrays (El-Kassaby and Lstibůrek 2009; El-Kassaby et al. 2011). Many studies reported strong influences of population and family and its effect on genetic diversity in progeny population (Liesebach et al. 2004; Gaspar et al. 2008; Hidayat and Siregar 2011; Çengel et al. 2012; Dering and Chybicki 2012) such as progeny test of Coffea arabica (Silveira et al. 2003), and seed orchard of Robinia 
pseudoacacia (Liesebach et al. 2004).

Genetic breeding of perennial plant species, such as forest essences, depends on the efficient selection of the best individuals to be used to obtain new plants with desirable traits. As such, it is important to adopt precise methods of selection. Progeny testing is essential to assessing genetic diversity, which is a prerequisite in any breeding program. The status of genetic diversity can be determined using several methods such as isozyme and other DNA based markers. In recent decades many molecular markers have been used to detect the genetic diversity within and among plant populations (Bharmauria et al. 2009). Molecular markers such as d RAPD (Random Amplified Polymorphic DNA) provide useful information related to evolution and population genetics (Kimura et al. 2009) and research genetic diversity between individual trees (Zarek 2009). Among molecular markers, RAPD markers have generally been used for the detection of genetic variation within and among populations in several plant species and populations without the need for detailed knowledge of DNA (Zarek 2009).

In particular, RAPD offers a cheap and simple DNA based marker alternative, considering the advantages of small amount of DNA, radioactivity-free procedure, ease and speed of the assay and lack of requirement for DNA sequence information of a species (Williams et al. 1990; Tingey et al. 1994; Ye et al. 1996; Martin et al. 1997). Although RAPD is of dominant marker, several strategies have been put forward to minimize the dominance effects on genetic variation analyses (Lynch and Milligan 1994). In occasional cases RAPD is poor in reproducibility, but this can usually be solved by the optimization of reaction conditions (Weising et al. 1994). In general, RAPD can provide valuable data about genetic variations within and among populations of a species, given that data (Collignon et al. 2002). This technique has been applied for detecting population genetic diversity of Toona sinensis (Wang et al. 2008; Hidayat and Siregar 2011), Toona australis (Tavares et al. 2012), Toona ciliata (Liu et al. 2014; Li et al. 2015), Melia azedarach (Yulianti 2011), Melia volkeensii (Runo et al. 2004), Lathyrus sativus (Nosrati et al. 2012),
Gmelina arborea (Wee et al. 2012), Quercus sp. (Dering and Chybicki 2012), Pinus nigra (Çengel et al. 2012), and Lansium domesticum (Song 2000).

There is an urgent need to initiate a program of genetic improvement, especially to develop seed orchard considering the increasing areas of surian plantation. Therefore, this experiment was carried out with aims at determining the patterns of individual genetic diversities of surian in progeny test based on RAPD marker, to support the improvement program of surian breeding strategy.

\section{Materials and methods}

\subsection{Sample collection}

Ninety-nine of $T$. sinensis samples were collected from progeny test. Origin of geographical location and materials used in this research has been established on progeny test of half-sib of surian in Candiroto, Central Java, Indonesia (Figure 1).

\subsection{DNA isolation}

Genomic DNA of 96 genotypes was extracted from 50$60 \mathrm{~g}$ dry individual surian leaves with CTAB (Cetyl Trimethyl Ammonioum Bromide) method modification (Shiraishi and Watanabe 1995).

\subsection{DNA purification}

DNA purification was performed using the Gene Clean III Kit. The principle of this method is to use of silica (glassmilk). The extraction result was then centrifugated and added $25 \mathrm{uL}$ psdH $\mathrm{H}_{2} \mathrm{O}$. After being vortexed, $300 \mathrm{uL}$ NAI was then added. Purification of the pellet was dried with a desiccator, then added $\mathrm{psdH}_{2} \mathrm{O}$ and vortexed. The obtanined DNA solution then stored in $1.5 \mathrm{~mL}$ microtube.

\subsection{DNA Quantification}

After purification, DNA was quantified by the GeneQuant (Parmacia). In GeneQuant, suitably diluted DNA in distilled water was read at A230, A260, A280 and A320 nm. GeneQuant Method of 1.8-2.0 to indicate a good DNA preparation. A 260 of 1 corresponds to $50 \mu \mathrm{g} / \mathrm{mL}$ of DNA
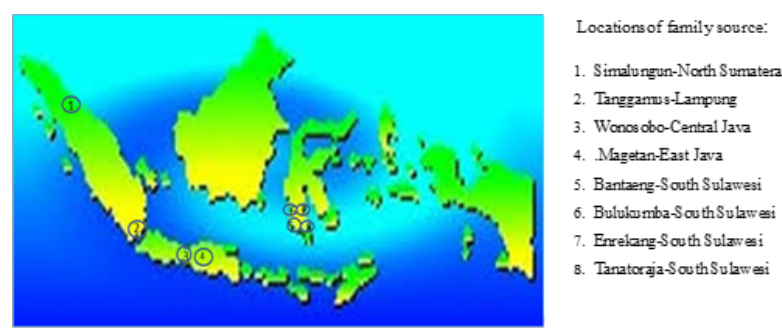

(a)

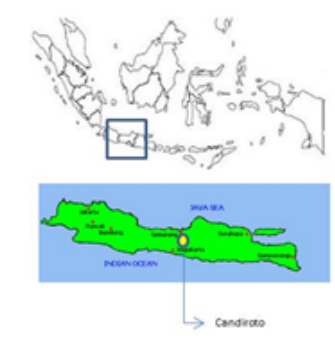

\begin{tabular}{ll}
\hline Description & $\begin{array}{l}\text { Temanggung District } \\
\text { Central Jawa Province }\end{array}$ \\
\hline Altitude & $07^{\circ} 06^{\prime} 208^{\prime \prime}$ (S) \\
Longitude & $110^{\circ} 10^{\prime} 131^{\prime \prime}(\mathrm{E})$ \\
Elevation & $710 \mathrm{~m}$ asl \\
Rain Fall (mm/year) & 2890 \\
Temperature (min- & $20^{\circ} \mathrm{C} \cdot 28^{\circ} \mathrm{C}$ \\
Max) & May - September \\
Dry Season & Undulating (slope 3-5\%) \\
Topography & Sandy clay \\
Soil & Acacia mangium \\
Previous Vegetation &
\end{tabular}

(b)

FIGURE 1 Approximate geographical locations of sampled family source of surian (a) and progeny test area (b). 
in a $1 \mathrm{~cm}$ quartz cuvette. The unknown DNA concentration can then be calculated.

\subsection{Dilution}

DNA dilution was intended to facilitate the use of quantified DNA solutions. The dilution of the purification volume was carried out based on the concentration of the quantified result by the addition of $\mathrm{psdH}_{2} \mathrm{O}$ according to the DNA concentration.

\section{6. $P C R$ amplification}

PCR amplification were carried out in a thermal cycler in a final volume of $10 \mu \mathrm{L}$, containing $4.0 \mathrm{uL}$ template DNA, $0.8 \mu \mathrm{L}$ of each of the four deoxynucleotide triphosphate, $0.5 \mathrm{uL}$ of primer, $1.2 \mathrm{mM} \mathrm{MgCl}_{2}, 10 \mathrm{x}$ Tag stofel buffer (10 mM Tris $\mathrm{HCl} \mathrm{pH} 9.0,50 \mathrm{mM} \mathrm{KCl}$ ) and $0.5 \mathrm{U}$ Taq DNA polymerase. The samples were further subjected for initial denaturation for $5 \mathrm{~min}$ at $94^{\circ} \mathrm{C}$, followed by $39 \mathrm{cy}-$ cles of $1 \mathrm{~min}$ at $94^{\circ} \mathrm{C}, 1 \mathrm{~min}$ at $39^{\circ} \mathrm{C}$ and $1 \mathrm{~min}$ at $72^{\circ} \mathrm{C}$ with a final extension of $7 \mathrm{~min}$ at $72^{\circ} \mathrm{C}$. $10 \mu \mathrm{L}$ of amplified PCR product was separated through gel electrophoresis on $1.5 \%$ agarose gel stained with ethidium bromide and photographed with gel documentation system (Sambrook et al. 1989).

\subsection{RAPD profiling}

The samples which showed the amplification with the selected primers were selected further for RAPD profiling. DNA fragment size on agarose gel was estimated by comparing with $1 \mathrm{~kb}$ DNA ladder. In this study, primers producing the total amount of polymorphic DNA bands were primers of OP-B3 (10 DNA bands), OP-B4 (4 DNA bands), OP-B10 (11 DNA bands), OP-H3 (4 DNA bands), OP-Y6 (9 DNA bands), OP-Y7 (9 DNA bands), OP-Y8 (11 DNA bands), OP-Y10 (7 DNA bands), OP-Y11 (6 DNA bands), OP-Y14 (7 DNA bands) and OP-O6 (4 DNA bands). In general, result of the amplification of eleven primers produced level of DNA band polymorphism for 30.5\% (25 polymorphic DNA bands). The polymorphic DNA bands were mostly produced in primers of OP-B10 and OP-Y8 (11 DNA bands with the polymorphism level of 50.0 and $18.2 \%$ ) and the least was produced in primers of OP-B4 and OP-O6 (4 DNA bands with the polymorphism level of 50\%). RAPD profile form DNA patterns of surian are shown in Figure 2.

\subsection{Data scoring and analysis}

Amplified bands generated from RAPD and RPCR amplification were scored based on the presence (1) or absence (0) of bands for each primer and were used to calculate a similarity matrix (SM) using NTSYS-pc version 2.02 (Rohlf 2000). SM were compiled for all pairs of individual using SM similarity coefficients, using SIMQUAL, and then cluster analysis was done using unweighted pairgroup method with arithmetic mean using the SAHN program. The cophenetic correlation was calculated to find

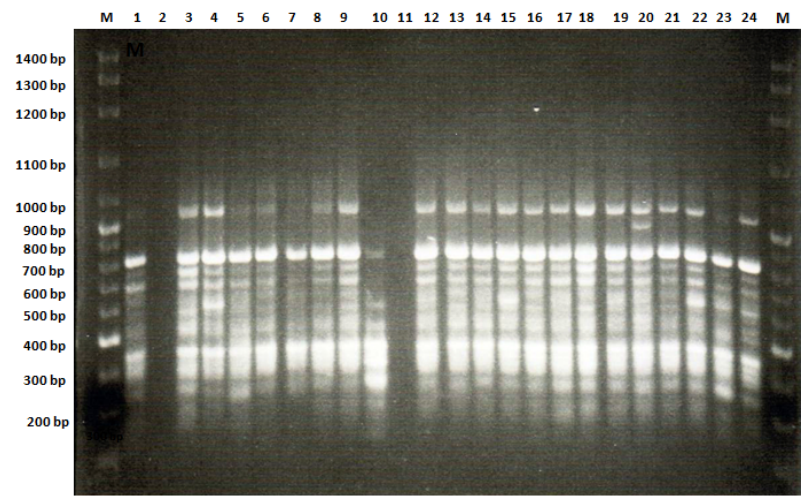

(a)

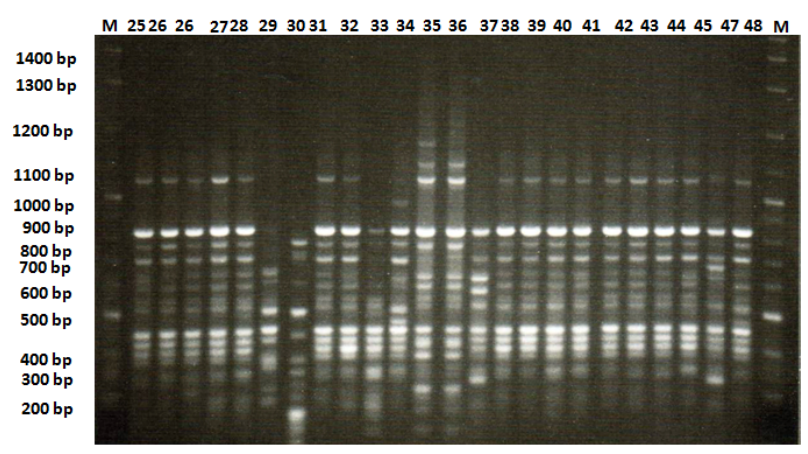

(b)

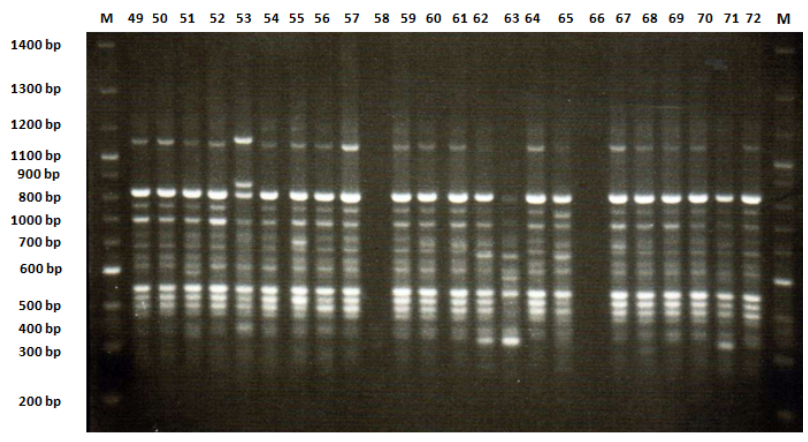

(c)

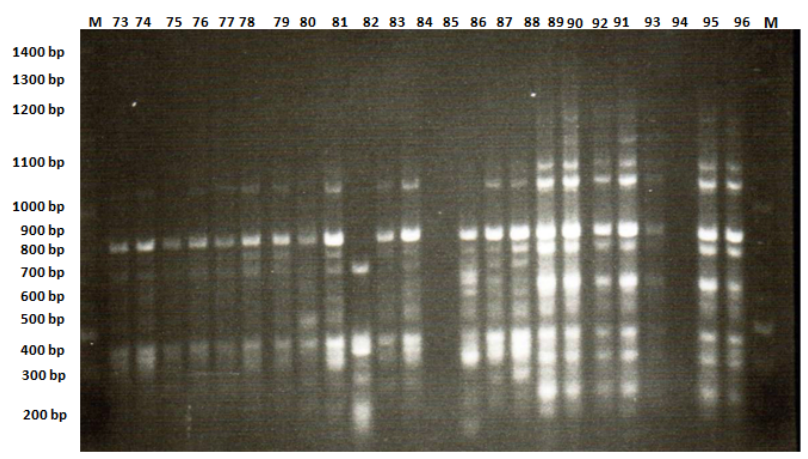

(d)

FIGURE 2 RAPD profile from primer OPB-10 (a) genotypes number 1-24, (b) genotypes number 25-48, (c) genotypes number 49-72 and (d) genotypes number 73-96.

the degree of association between the original SM and the tree matrix in molecular analyses. Using the same software, Principal Coordinate Analysis (PCoA) was per- 
formed by GenAlex 6.3 to identify any genetic association among the genotypes and visualize the genetic distance between individual in two hierarchies as two steps. First, a primary PCoA was conducted at individual and family level. Second PCoA was then conducted for each cluster obtained from the primary PCoA. In addition, Unweighted Pair Group Method with Arithmetic Mean (UPGMA) clustering were performed with the program NTSYS-pc version 2.02 (Rohlf 2000), based on pairwise Nei's unbiased genetic identity (Nei 1972) calculated between family with GenAlEx (Peakall and Smouse 2006).

\section{Results and discussion}

\subsection{RAPD fragment}

The amplification of PCR-RAPD with eleven primers produced 82 patterns of DNA bands (Table 1). The highest diversity in DNA band patterns was resulted from primers of OPB-10 (5 polymorphic) and OPB-03 (3 polymorphic), OPY-06 (3 polymorphic) patterns, respectively, while lowest diversity in DNA band patterns was resulted from primer of OPY-11 and OPY-14 (1 polymorphic) patterns respectively. RAPD used differences in the pattern of PCR amplification generated form differences in its attaching position of primers at genome DNA from the different individuals. The difference in DNA band pattern was because of the amplification of DNA sequence at certain positions (Weeden et al. 1992). Differences in base pairs (bp) in the DNA sequence cause amplification not to be performed due to incompatibility between the primer and complementary DNA sequences.

RAPD analysis can be used to determine and recognize the characteristics of genetic diversity between plant genotypes, and the genetic diversity can be seen in DNA polymorphism (Wang et al. 2010). The mean genetic diversity between surian progeny (He) was categorized as moderate (0.304). This level of variation was corroborated by other variables such as percentage of polymorphic loci
(PPL), ranging $18.2-50 \%$ with an average of 30.5\%. The PPL value in this study was higher than previous RAPD studies of T. sinensis in West Java (Hidayat and Siregar 2011) and Toona ciliata in China (Li et al. 2015), but lower than one of T. sinensis in China (Wang et al. 2008).

Among the 96 individual being tested there are several factors that affect the level of genetic diversity of a species within a population source, such as effective size of population, mutation, genetic drift, migration, mating system, selection and production of flower and pollen (Lemes et al. 2003; Finkeldey and Hattemer 2005). The moderate level of genetic diversity of $T$. sinensis at progeny test could be as a consequence of a small population size, this situation have been proved by T. sinensis (Hidayat and Siregar 2011), T. ciliata (Wang et al. 2008) and Melia azedarach (Yulianti 2011). The small population size also can increase the possibility of genetic drift, which will reduce the genetic diversity as a result of bottlenecking and inbreeding (Lorenz 2012). Other genetic parameter being measured was value of expected heterozygosity (He) with the value of Hewas 0.304 . This He value in this study was similar to those of $T$. ciliata in China (He 0.305 in Liu et al. (2014); He 0.378 in Li et al. (2015)), T. sinensis in West Java (He 0.240) and T. sinensis in China (He 0,333 in Wang et al. (2008)).

\subsection{Genetic relationship and clustering analysis}

A dendrogram based on the similarity index values was generated using UPGMA. As Figure 3 shows, the resultant dendrogram was separated into 2-main clusters at genetic similarity coefficient of 0.46 and 7 -sub clusters at genetic similarity coefficient of 0.56 . Sub cluster III/A-3 was separated into two sub-sub clusters at genetic similarity coefficient of 0.580 with sub-sub cluster III/A-3-1 (consisted of 2 family) and III/B-3-2 (consisted of 4 individuals). Sub cluster V was separated into two subsub clusters at genetic similarity coefficient of 0,592 with sub-sub cluster V/B-2-1 (consisted of 2 family), V/B-2-

TABLE 1 Number of RAPD fragment, fragment size, and number of polymorphic fragment from each primer to be used.

\begin{tabular}{|c|c|c|c|c|c|c|}
\hline Primer & Sequence (5'-3') & G+C Composition (\%) & $\begin{array}{l}\text { Fragment } \\
\text { number }\end{array}$ & $\begin{array}{l}\text { Polymorphic } \\
\text { fragment }\end{array}$ & Percentage (\%) & Fragment size (Base Pair/bp) \\
\hline OP-B3 & CATCССССТG & 70 & 10 & 3 & 30 & $300,600,800$ \\
\hline OP-B4 & GGACTGGAGT & 60 & 4 & 2 & 50 & 400,650 \\
\hline OP-B10 & CTGCTGGGAC & 70 & 11 & 5 & 45.5 & $340,350,500,620,680$ \\
\hline OP-H3 & AGACGTCCAC & 60 & 4 & 2 & 50 & 500,800 \\
\hline OP-Y6 & AAGGCTCACC & 60 & 9 & 3 & 33.3 & $380,700,900$ \\
\hline OP-Y7 & AGAGCCGTCA & 60 & 9 & 2 & 22.2 & 450,700 \\
\hline OP-Y8 & AGGCAGAGCA & 60 & 11 & 2 & 18.2 & 500,650 \\
\hline OP-Y10 & CAAACGTGGG & 60 & 7 & 2 & 28.6 & 500,700 \\
\hline OP-Y11 & AGACGATGGG & 60 & 6 & 1 & 16.7 & 380 \\
\hline OP-Y14 & GGTCGATCTG & 60 & 7 & 1 & 14.3 & 500 \\
\hline OP-O6 & CCACGGGAAG & 70 & 4 & 2 & 50 & 450,650 \\
\hline
\end{tabular}




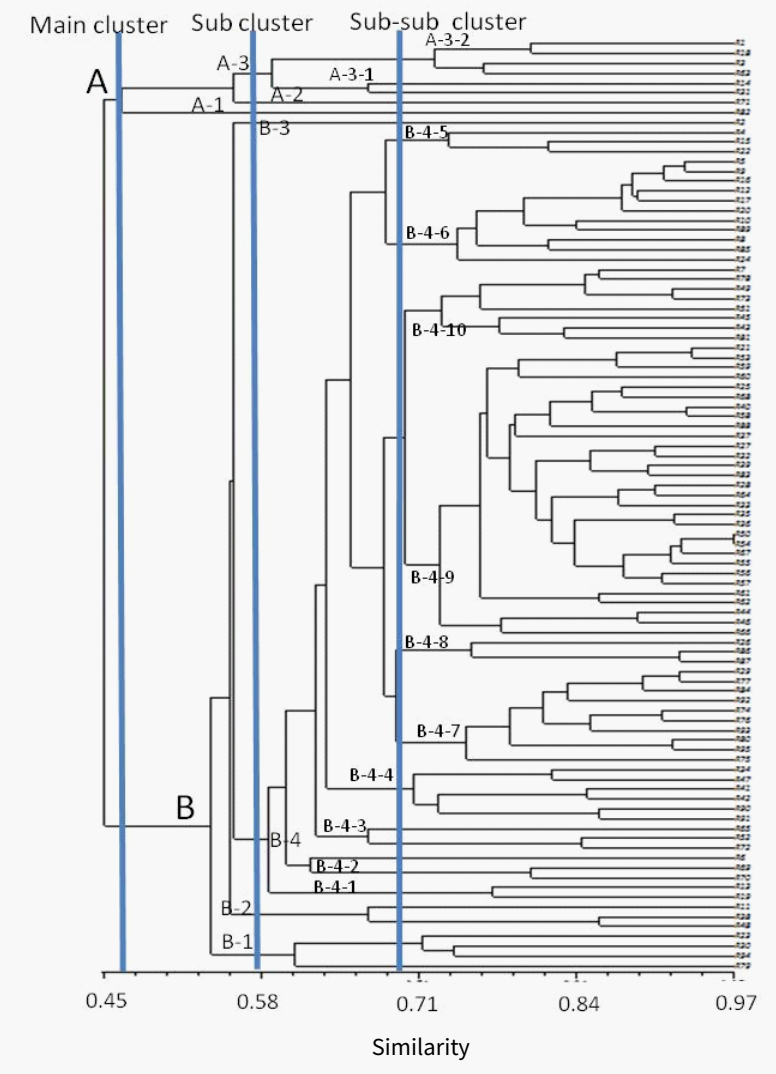

FIGURE 3 UPGMA-dendogram of genetic similarity among 96 Toona sinensis individuals of progeny test base on RAPD Data.

2 (consisted of 3 individuals from 3 family). Sub cluster VII/B-4 consisted of 10 sub-subclusters are VII/B-4-1 (consisted of 3 individuals), VII/B-4-2 (consisted of 3 individuals), VII/B-4-3 (consisted of 6 individuals), VII/B-4-4 (consisted of 30 individuals), VII/B-4-5 (consisted of 8 individuals), VII/B-4-6 (consisted of 3 individuals), VII/B4-7 (consisted of 11 individuals), VII/B-4-8 (consisted of 10 individuals), VII/B-4-9 (consisted of 3 individuals) and Sub clusterVII/B-4-10 (consisted of 2 individuals).

Based on the dendrogram (Figure 3), the grouping was not in accordance with family and population. The grouping of several individual trees did not indicates that family distance is closer, but more to its genetic similarity. It shows genetic diversity in the individual of surian, being possibly caused by the recombination of genes. According to Çengel et al. (2012), the grouping based on the geographic positions taken place because the RAPD marker indicates DNA variation, both in coding and non-coding regions. Moreover, RAPD property was not reproducible to get an accurate grouping. The same result was shown from previous study on some family of surian in West Java (Hidayat and Siregar 2011), where the formed pattern of grouping did not show the grouping based on the region of origin (sampling location). In this study indicates that there are several individual trees originating form the same family do not form single group but are scattered in sev- eral group. its was different with data reported by Song (2000), indicating that the grouping was generally appropriate with its geographic region of origin. Result of the analysis on the genetic relatedness of individual progeny test of surian and the RAPD approach showed that mix individual from a were grouped as several sub cluster and sub-sub cluster.

In this study showed that there is no spesific allel, number of different alleles observed (na $=1.725$ ), number of effective alleles (ne $=1.533$ ), Shannon's information index ( $\mathrm{I}=0.449)$, expected heterozygosity $(\mathrm{He}=0.304)$, and unbiased expected heterozygosity $(\mathrm{UHe}=0.318)$. Genetic distance (Nei 1972) showed 0.002 to 0.161 with the average value was 0.069 . The value of similarity showed 0.998 to 0.847 with average value 0.935 . The value genetic distance of among surian in progeny test was lowest than genetic distance of $T$. sinensis (Meliaceae) in West Java (0.440 in (Hidayat and Siregar 2011) and M. azedarach (Meliaceae) in West Java (0.192 in Yulianti (2011)).

Based on Table 2, there were 7 sub clusters and 14 subsub clusters which has the biggest sub cluster VII have the number 79 individual. Sub-sub clusters 6/B-4-4 have 31 individuals, followed by sub-sub cluster 9/B-4-7 with 11 individuals and sub-sub cluster 10/B-4-8 with 10 individuals, which all individuals that compose is a cross family. Selection is based on sub-sub cluster is quite important to be considered for individual which are distributed in subsub clusters have a genetic similarity.

\subsection{Genetic relatedness based on RAPD}

The use of Jaccard's similarity coefficient to estimate genetic relatedness among accessions gave similarity value ranging from 0.43 to 0.97 that mean genetic similarity between the major clusters of Toona sinensis individual ranged from $43 \%$ to $97 \%$, as shown in Figure 4 . This coefficient genetic similarity in this study was similar to those of Pinus sylvestris progeny range 0.69 to 0.94 (Cipriano et al. 2013). For comparison study on Melia azedarach in community forest founded that the similarity index values of 0.02-0.65, indicating a small genetic variation among the family (Yulianti 2011).

The high level of similarity among the individuals of surian was because the plants of surian individual originated from small population scattered in the community forest. Other possibility was the event of cross-pollination because the plants of surian were annual plants whose existence was still in community forest. Principle components analysis was used to identify the most significant variable in the data set. The result indicated that the first component explain about $45.16 \%$ of the total variability observed, where by the second accounted for $25.54 \%$.

Principal Coordinate Analysis (PCoA) was performed to identify relationship the most significant variable in data set. PCoA based determined by Eigen value. Eigen value under the one $(<1)$ not used for the review identify. Based on the PCoA analysis on Figure 4a shows the main 
TABLE 2 Cluster membership of various Toona sinensis progeny test.

\begin{tabular}{|c|c|c|c|c|c|c|}
\hline $\begin{array}{l}\text { Main } \\
\text { cluster }\end{array}$ & Subcluster & Sub-subcluster & Total & Genotypes number & Origin of Family & $\begin{array}{r}\text { Similarity } \\
\text { Coefficient (\%) }\end{array}$ \\
\hline \multirow[t]{4}{*}{$I(A)$} & I/A-I & - & 1 & 82 & BLK & 47.6 \\
\hline & II/A-II & - & 1 & 72 & BLK & 53.9 \\
\hline & III/A-III & 1/A-3-1 & 4 & $23,30,94,79$ & MGT, LPG, SMT, BLK & 53.9 \\
\hline & & $2 / A-3-2$ & 2 & 38,48 & WSB, TRJ, TRJ & 52.2 \\
\hline \multirow[t]{14}{*}{ II (B) } & IV/B-1 & - & 1 & 71 & BTG & 65.7 \\
\hline & V/B-2 & 1/B-2-1 & 2 & 14,31 & MGT, LPG & 65.8 \\
\hline & & $2 / \mathrm{V}-2-2$ & 4 & $1,8,3,63$ & WSB, MGT, BTN & 72.7 \\
\hline & $\mathrm{VI} / \mathrm{B}-3$ & - & 1 & 2 & WSB & 65.9 \\
\hline & VII/B-4 & 3/B-4-1 & 3 & $6,69,70$ & WSB, BTG & 62.2 \\
\hline & & 4/B-4-2 & 3 & $65,52,71$ & ERK, BTG, ERK & 67.2 \\
\hline & & $5 / B-4-3$ & 6 & $34,47,41,42,90,91$ & LPG, TRJ, SMT, SMT & 73.1 \\
\hline & & 6/B-4-4 & 31 & $\begin{array}{l}21,53,59,60,25,28,40,58,88,37,27 \\
32,39,83,28,64,33,35,36,50,54,67 \\
55,56,57,61,62,44,46,66,11\end{array}$ & $\begin{array}{l}\text { MGT, LPG, TRJ, } \\
\text { ERK, BTG, BLK }\end{array}$ & 73.1 \\
\hline & & $7 / B-4-5$ & 8 & $7,78,49,73,51,45,43,81$ & WSB, TRJ, ERK, BLK & 73.3 \\
\hline & & $8 / B-4-6$ & 3 & $4,15,22$ & WSB, MGT & 73.6 \\
\hline & & $9 / \mathrm{B}-4-7$ & 11 & $5,9,16,12,17,20,10,89,8,85,24$ & WSB, MGT, SMT & 74.5 \\
\hline & & 10/B-4-8 & 10 & $29,77,84,92,74,76,93,80,95,75$ & LPG, BLK, SMT, SMT & 74.9 \\
\hline & & 11/B-4-9 & 3 & $26,86,87$ & LPG, SMT & 75.1 \\
\hline & & 12/B-4-10 & 2 & 13,19 & MGT & 76.2 \\
\hline
\end{tabular}

Notes: SMT (Sumatera Utara), LPG (Lampung), WSB (Wonosobo), MGT (Magetan), BTG (Bantaeng), BLK (Bulukumba), ERK (Enrekang), TRJ (Tanatoraja).

components was be able to explain the accumulative variation of $70.70 \%$. Base on principal component is used to review describes patterns of diversity and relationships among individual plants of surian.

The relationships between individual surian tested are shown in scattered matrix principal components divided being four quadrants. Individuals trees (code as given in Table 2 and Figure 4) in the same quadrant that shows the nearer genotype but if located in different quadrant that indicating a genotype has relationship away. The scattered matrix (Figure 4a) showed the individual trees of different family distributed and overlapped in one quadrant have nearest genotype or have a close relationship.

The information from PCoA analysis is then used to review the placement maps of families in progeny test originally arranged based on randomization to separate families from adjacent sites without being equipped genetic information. Ideally, the family distribution map in the progeny test is capable of separating families with genetic proximity but in the $3^{\text {rd }}$ replication plot there are still families located adjacent to 78 and 94 (Figure 4b, A) and at $4^{\text {th }}$ replication families 78 and 81 (Figure 4b, C) and families 115 and 7 (Figure 4b, A). The role of genetic information to manage the layout of family placement in progeny test is essential to be involved for next period.

\subsection{Implication and recommendation for designing the breeding strategy}

Our results emphasized that basically genetic diversity is the foundation for maintaining genetic evolutionary processes of $T$. sinensis. Hence, to define breeding strategy, our main recommendation is in maintaining those processes within the family and the origin population as the genetic base in progeny test. Genetic diversity is a fundamental tenet of the conservation ethic, and that genetic diversity is an important consideration when managing forest stands, ecosystem and landscapes (Libby 1973).Yet, the extent and distribution of genetic diversity are preconditions for the adaptation that determines the long-term stability of individual species and entire ecosystems (Vellend and Geber 2005).

Genetic diversity is the most important component of biodiversity. It is the foundation of ecosystem stability and forest sustainability because genetic diversity provides raw material for evolution, survival and adaptation of the species, especially under changed environmental conditions. Genetic diversity needs to be assessed in longterm genetic resource collections, in breeding populations, in seed orchards or planting materials producing populations (Muona 1990). The purpose of these tests are to provide genetic information about the select parent trees and 


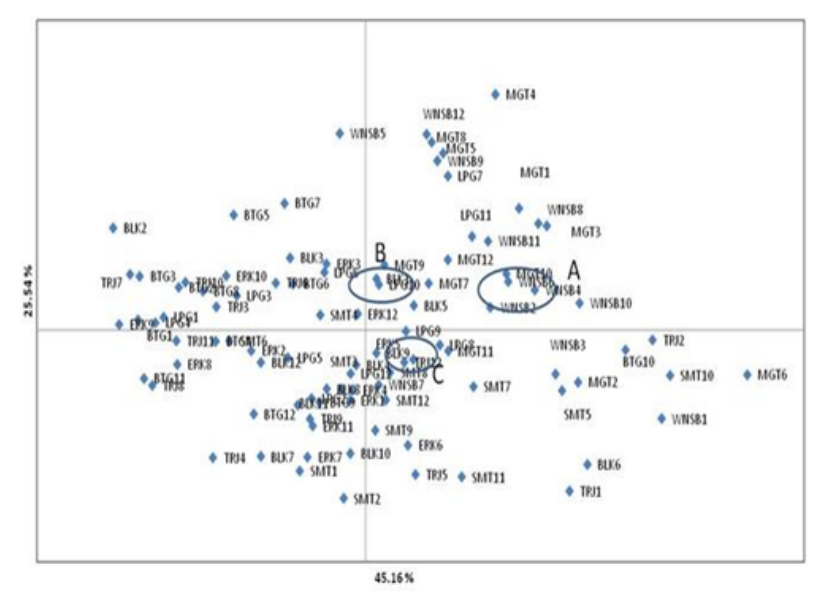

(a)
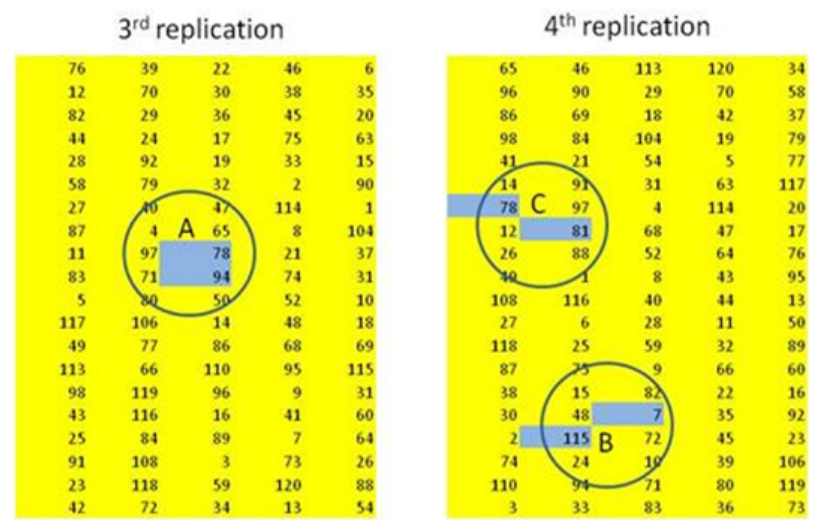

(b)

FIGURE 4 Comparison scattered distribution of 96 Individual of Toona sinensis based on PCoA Analysis using 11 RAPD Primers (a) and layout placement family at progeny test (b).

to provide an improved population of trees from which the next generation of select trees is made. Tree families established in progeny tests are randomized and replicated in a designed manner to meet statistical and genetic criteria. Families are planted in several sites and in more than one year to sample an adequate number of environmental conditions. T. sinensis tree progeny tests are intensively managed similarly to a typical industrial forest plantation. Growth and quality measurements are made periodically in these tests until harvest. These data are entered into a data base and analyzed. The results are used to assess the genetic worth of the original selections, to make selections for the next generation and to make recommendations for establishing and upgrading seed and hedge orchards.

In order to determine whether the genetic diversity in maternal populations is transmitted to progeny populations and how much its value is recommended to test the seeds derived from the progeny test in the next phase. Dering and Chybicki (2012) reported gene diversity progeny decrease by $3.73 \%$ but increase by $1.26 \%$ in plantation. Based on the previous information it is necessary to conduct research activities to complete the basic information for improvement to breeding programme include 3 steps.
First to identify changes in genetic diversity from last year to the next Second to determining the number of individual tree which will represent families or populations in the progeny test. Third to corrected assignment of progeny to half-sib families based on genotypic information would to change result assessment of family rank for growth and quality traits. We recommend that assessment of growth traits be based on qualitative and quantitative traits based on genetic test data to accurately rank families and populations. The next activity is to compare the average value of the individual genotype with the progeny test map at the time of planting base on phenotypic trait. The lowest variation in subsequent generations might result from the reduction in effective population size as well. The estimated effective population size was studied at progeny plantation.

For genetic diversity of $T$. sinensis found in this study has two recommend. First to evaluated in terms of genetic gain expected for traits of importance, usually over a period of time. Second to evaluated mating system of $T$. sinensis populations expected gain could be utilised by a proposed selection and propagation system. Several longterm breeding strategies are now available, which are designed to retain sufficient genetic variability to counter act the risks of inbreeding in future generations. Mating pattern could be utilised by a proposed management breeding strategy. In recent years, different strategies and methods have been proposed and used to widen the genetic base of breeding populations for long-term breeding. In addition, efforts should also to get quality resource of $T$. sinensis we proposed to establishment of seed production areas from progeny test conversion is featured as the most effective and time-efficient strategy for short-term improvement. For long-term sustainable tree production as well as quality seed yield, seed orchards are suggested.

\section{Conclusions}

Results from the RAPD analysis of the progeny arrays showed that $T$. sinensis had a medium level genetic diversity (He 0.304$)$. This value was sufficient to become the base genetic resources for the development of surian breeding populations in the advanced phase. Clustering analysis at genetic similarity coefficient of 0.58 and 0.46 the were identified two main clusters, seven subclusters and fourteen sub-subclusters. Groupings between subgroups are not shown that family distance is closer, but based on their genetic similarities. Our results emphasized the importance of PCoA analysis to be used to improve the pattern of family randomization for dissociate families that have genetic similarities in the progeny plot for next phase.Furthermore, to increase genetic diversity of surian forest community can be used as a source of genetic materials from progeny test. Breeding population preparation must consider the existence genetic distance of individual T. sinensis in progeny plot. 


\section{Acknowledgments}

This study was part of a long-term research on Toona spp. Genetic Conservation and Improvement, supported by the Centre for Forest Biotechnology and Tree Improvement Research and Development (Balai Besar Penelitian dan Pengembangan Bioteknologi dan Pemuliaan Tanaman Hutan, BBPPBTH). Wahyunisari, Maryatul Qiptiyah (assistance laboratory works in the Molecular Genetics Laboratory-BBPPBTH), ILG Nurcahyaningsih, AYPBC Widyatmoko (providing advice in the analyses). Many thanks go to all the team of the Molecular Genetic Laboratory for their excellent technical assistance.

\section{Authors' contributions}

J, IN, SI, MN, EBH designed the study. J, IN carried out the laboratory work. J, IN analyzed the data. J, IN wrote the manuscript. IN, SI, MN, EBH proofread the manuscript. J, SI, MN, EBH, IN have read and approved the final version of the manuscript.

\section{Competing interests}

The authors declare no competing interest.

\section{References}

Bharmauria V, Narang N, Verma V, Sharma S. 2009. Genetic variation and polymorphism in the Himalayan nettle plant Urtica dioica based on RAPD marker. J Med Plants Res. 3:166-170.

Çengel B, Tayanç Y, Kandemir G, Velioglu E, Alan M, Kaya Z. 2012. Magnitude and efficiency of genetic diversity captured from seed stands of Pinus nigra (Arnold) subsp. pallasiana in established seed orchards and plantations. New Forests 43:303-317. doi:10.1007/s11056-011-9282-8.

Cipriano J, Carvalho A, Fernandes C, Gaspar MJ, Pires J, Bento J, Roxo L, Louzada J, Lima-Brito J. 2013. Evaluation of genetic diversity of Portuguese Pinus sylvestris L. populations based on molecular data and inferences about the future use of this germplasm. J Genet. 92:e41-48.

Collignon AM, Sype HVd, Favre JM. 2002. Geographical variation in random amplified polymorphic DNA and quantitative traits in Norway spruce. Can J For Res. 32:266-282. doi:10.1139/x01-198.

Dering M, Chybicki I. 2012. Assessment of genetic diversity in two-species oak seed stands and their progeny populations. Scand J For Res. 27:2-9. doi:10.1080/02827581.2011.631934.

Edmonds JM, Staniforth M. 1998. Plate 348. Toona sinensis. Curtis’s Bot Mag. 15:186-193. doi:10.1111/14678748.00169.

El-Kassaby YA, Cappa EP, Liewlaksaneeyanawin C, Klápště J, Lstibůrek M. 2011. Breeding with- out breeding: is a complete pedigree necessary for efficient breeding? PLOS ONE 6:e25737. doi:10.1371/journal.pone.0025737.

El-Kassaby YA, Lstibůrek M. 2009. Breeding without breeding. Genet Res. (Camb) 91:111-120. doi:10.1017/S001667230900007X.

Finkeldey R, Hattemer HH. 2005. Pengantar genetika hutan. Bogor: ASEAN-EU University Network Programme (AUNP) Fakultas Kehutanan IPB. Translation of: Tropical Forest Genetics.

Gaspar MJ, Louzada JL, Silva ME, Aguiar A, Almeida MH. 2008. Age trends in genetic parameters of wood density components in 46 half-sibling families of Pinus pinaster. Can J For Res. 38:1470-1477. doi:10.1139/X08-013.

Hidayat H, Siregar IZ. 2011. Preliminary evaluation on genetic variation of two year old surian (Toona sinensis Roem) progeny test assessed by rapd marker.

Kimura T, Yagi M, Nishitani C, Onozaki T, Ban Y, Yamamoto T. 2009. Development of SSR markers in carnation (Dianthus caryophyllus). J Jpn Soc Hortic Sci. 78:115-123.

Lemes MR, Gribel R, Proctor J, Grattapaglia D. 2003. Population genetic structure of mahogany (Swietenia macrophylla King, Meliaceae) across the Brazilian Amazon, based on variation at microsatellite loci: implications for conservation. Mol Ecol. 12:2875-2883.

Li P, Zhan X, Que Q, Qu W, Liu M, Ouyang K, Li J, Deng X, Zhang J, Liao B, Pian R, Chen X. 2015. Genetic diversity and population tructure of Toona ciliata Roem. based on sequence-related amplified polymorphism (SRAP) markers. Forests 6:1094-1106. doi:10.3390/f6041094.

Libby WJ. 1973. Domestication strategies for forest trees. Can J For Res. 3:265-276. doi:10.1139/x73-036.

Liesebach H, Yang MSY, Schneck V. 2004. Genetic diversity and differentiation in a black locust (Robinia pseudoacacia L.) progeny test. Int J For Gen. 11:151161.

Liu J, Jiang JM, Chen YT. 2014. Genetic diversity of central and peripheral populations of Toona ciliata var. pubescens, an endangered tree species endemic to China. Genet Mol Res. 13:4579-4590. doi:10.4238/2014.June.17.10.

Lorenz TC. 2012. Polymerase chain reaction: basic protocol plus troubleshooting and optimization strategies. J Vis Exp. 63:3998. doi:10.3791/3998.

Lynch M, Milligan BG. 1994. Analysis of population genetic structure with RAPD markers. Mol Ecol. 3:9199.

Martin C, Gonzalez-Benito ME, Iriondo JM. 1997. Genetic diversity within and among populations of a threatened species: Erodium paularense Fern. Gonz. \& Izco. Mol Ecol. 6:813-820. doi:10.1046/j.1365294X.1997.00250.x. 
Muona O. 1990. Population genetics in forest tree improvement. In: AHD Brown, MT Clegg, AL Kahler, BS Weir, editors. Plant population genetics, breeding, and genetic resources. Sunderland, Massachusetts: Sinauer Associates Inc.. p. 282-298.

Nei M. 1972. Genetic distance between populations. Am Nat. 106:283-292.

Nosrati H, Hosseinpour-Feizi MA, Nikniazi M, RazbanHaghighi A. 2012. Genetic variation among different accessions of Lathyrus sativus (Fabaceae) revealed by RAPDs. Bot Serbica 36:41-47.

Peakall R, Smouse PE. 2006. GENALEX 6: genetic analysis in excel. population genetic software for teaching and research. Mol Ecol Notes 6:288-295. doi:10.1111/j.1471-8286.2005.01155.x.

Pennington TD, Styles BT. 1975. A generic monograph of the Meliaceae. Nationaal Herbarium Nederland- Universiteit Leiden branch.

Pramono AA, Danu, Rohandi A, Royani H, Abidin AZ, Supardi E, Nurokhim N. 2008. Distribution of potential seed sources of potential surian types in Java. LHP No. 498. Bogor: Research Institute for Seeding Technology.

Rohlf F. 2000. NTSYS-pc - Numerical taxonomy and multivariate analysis system version 2.0. New York: Applied Biostatistics Inc.

Runo MS, Muluvi GM, Odee DW. 2004. Analysis of genetic structure in Melia volkensii (Gurke.) populations using random amplified polymorphic DNA. Afr J Biotechnol. 3:421-425.

Sambrook J, Fritsch EF, Maniatis T. 1989. Molecular cloning: a laboratory manual.. $2^{\text {nd }}$ edition. Cold Spring Harbor, NY: Cold Spring Harbor Laboratory Press.

Shiraishi S, Watanabe A. 1995. Identification of chloroplast genome between Pinus densiflora Sieb. et Zucc. and $P$. thunbergii Parl. based on the polymorphism in rbcL gene. J Jpn For Soc. 77:429-436.

Silveira SR, Ruas PM, Ruas CdF, Sera T, Carvalho VdP, Coelho ASG. 2003. Assessment of genetic variability within and among coffee progenies and cultivars using RAPD markers. Gen Mol Biol. 26:329-336. doi:10.1590/S1415-47572003000300018.

Song B. 2000. Genetic relatedness among Lansium domesticum accessions using RAPD markers. Ann Bot. 86:299-307. doi:10.1006/anbo.2000.1186.

Tavares R, Viana AP, Barroso DG, Júnior A, Do AT. 2012. Genetic diversity in Australian Cedar genotypes selected by mixed models. Cienc Agrotecnol. 36:171179. doi:10.1590/S1413-70542012000200005.

Tingey SV, Rafalski JA, Hanafey MK. 1994. Genetic analysis with RAPD markers. In: Plant molecular biology. NATO ASI Series. Berlin: Springer. p. 491-500. doi:10.1007/978-3-642-78852-9_45.

Vellend M, Geber MA. 2005. Connections between species diversity and genetic diversity. Ecol Lett. 8:767-781. doi:10.1111/j.1461-0248.2005.00775.x.

Wang BY, Shi L, Ruan ZY, Deng J. 2010. Genetic diversity and differentiation in Dalbergia sissoo (Fabaceae) as revealed by RAPD. Gen Mol Res. 10:114-120. doi:10.4238/vol10-1gmr995.

Wang C, Cao J, Tian S, Wang Y, Chen Z, Chen M, Gong G. 2008. Germplasm resources research of Toona sinensis with RAPD and isoenzyme analysis. Biologia 63:320-326. doi:10.2478/s11756-008-0066-3.

Wee AKS, Li C, Dvorak WS, Hong Y. 2012. Genetic diversity in natural populations of Gmelina arborea: implications for breeding and conservation. New For. 43:411-428. doi:10.1007/s11056-011-9288-2.

Weeden NF, Timmerman GM, Hemmat M, Kneen BE, Lodhi MA. 1992. Inheritance and reliability of RAPD markers. In: Application of RAPD technology to plant breeding. Crop Science Society of America. Madison: Joint Plant Breeding Symposia Series. p. 12-17.

Weising K, Nybom H, Pfenninger M, Wolff K, Meyer W. 1994. DNA Fingerprinting in Plants and Fungi. CRC Press.

Williams JG, Kubelik AR, Livak KJ, Rafalski JA, Tingey SV. 1990. DNA polymorphisms amplified by arbitrary primers are useful as genetic markers. Nucleic Acids Res. 18:6531-6535.

Xing PY, Liu T, Song ZQ, Li XF. 2016. Genetic diversity of Toona sinensis Roem in China revealed by ISSR and SRAP markers. Genet Mol Res. 15. doi:10.4238/gmr.15038387.

Ye GN, Hemmat M, Lodhi MA, Weeden NF, Reisch B. 1996. Long primers for RAPD mapping and fingerprinting of grape and pear. BioTechniques 20:368371.

Yulianti Y. 2011. Genetic variation of Melia azedarach in community forests of West Java assessed by RAPD. Biodiversitas 12:64-69. doi:10.13057/biodiv/d120202.

Zarek M. 2009. RAPD analysis of genetic structure in four natural populations of Taxus baccata from southern Poland. Acta Biol Cracov Ser Bot. 51:67-75.

Zhou GX, Zhang BG, Lin L, Qin Z, Lin G, Ya-Yun P, Xia C. 2010. Study on the relationship between Toona sinensis Roem stand productivity and site conditions in Sichuan Basin. Ecol Econ. 6:387-394.

Zobel B, Talbert J. 1984. Applied forest tree improvement. New York: John Wiley and Sons. 